\section{"Shot in the arm" for Japan's program}

Tokyo

JAPAN's Human Frontiers Science Program received a shot in the arm on 29 April when scientists from the seven Western summit nations (Japan, Canada, Britain, France, Italy, West Germany and the United States) and the European Community met in Bonn and declared enthusiastic support for the project and called for its implementation at the earliest possible date. But it will be the end of this year before it becomes clear how much Japan is prepared to put into the programme.

The Bonn "Wise Men's Conference", supported by the Japan Science Foundation and the Alexander von Humboldt Foundation, follows a meeting of the summit nation scientists in Tokyo in March at which it was decided that Frontiers should promote international basic research on the brain and the molecular mechanisms of biological functions by awarding research grants and fellowships through international peer review and by staging frequent workshops. The scientists estimated that an annual budget of about $\$ 80-\$ 100$ million would be appropriate in the initial phase.

Japan's Prime Minister, Noboru Takeshita, is expected to raise Frontiers at the next summit in Toronto in June. Takeshita has expressed support for the programme and it is in line with his recent calls for increased trilateral collaboration between Japan, Europe and the United States. But it is unlikely that he will be able to put any money on the table at Toronto.

Although Frontiers was initiated by the Ministry of International Trade and Industry (MITI), the chief responsibility for negotiating the budget has swung to the Science and Technology Agency (STA). MITI is taking a backstage role in the project partly because Western suspicions about a trade and industry ministry being involved in a basic research project was giving the programme a poor image. But the agency does not have the same clout as MITI. Furthermore, the Ministry of Finance, which will allot the budget for Frontiers, is divided into sections for each ministry, and while MITI's section in the Finance Ministry is thoroughly familiar with the programme after two years of negotiations, there are some newcomers in STA's section and budget negotiations are expected to be prolonged. STA and MITI will submit their budget requests to the Finance Ministry at the end of August.

In these circumstances, it seems unlikely that other summit nations will make any financial commitment at Toronto. But MITI officials are confident that in the long term at least France and West Germany will contribute funds to the programme.

David Swinbanks

\title{
Little hope of Yuppiedom for benchbound scientists
}

\section{London}

THE principle discovery of the alchemists, that you won't get rich at the laboratory bench, still holds true - at least for British scientists. A study by an independent group of salary analysts, Income Data Services (IDS) ${ }^{*}$, confirms what scientists here have known for years: "The pay levels for professional engineers and scientists compare unfavourably with the earnings of other professional groups."

According to the study, the average gross annual salary for full-time males in science, engineering and technology was, at April last year, $£ 13,884(\$ 25,825)$. This compares with $£ 17,056$ for professionals supporting management and administration; $£ 18,876$ for personnel officers and managers; £19,188 for marketing and sales managers and executives; and $£ 24,700$ for finance, insurance and tax specialists. For women scientists the situation is even more dire, with the average annual gross salary at only $£ 9,261$. The report offers no explanation for this.

For those scientists who resist the poaching efforts of the financial sector, a move into management and administration usually means a jump of several rungs up the salary ladder. IDS found last year that for most research and development specialists without management responsibility there was a salary bar of between $£ 16,000$ and $£ 20,000$. Earlier this year, a survey by the Royal Society of Chemistry showed that median earnings for its members in general management were $£ 27,800$; research and development pri- marily as a manager or administrator, $£ 22,000$; marketing and sales, $£ 21,000$; and research and development without substantial management or administrative responsibilities, $£ 15,300$. Similarly, the Institution of Mechanical Engineers found that general administration paid well with earnings of around $£ 27,200$ for the 50-54 age group. The Institution of Civil Engineers recorded $£ 20,350$ for members in marketing and sales, but only $£ 15,000$ for those in development and design.

The IDS study found that in general the public sector pays less well than the private sector, and thus has had to introduce several counter measures to poaching by private firms. In particular, new salary structures have been introduced to allow merit payments and opportunities for faster promotion. Poaching is particularly acute in the financial sector. "There are signs that newly qualified scientists and engineers, with their numerate, logical and analytical minds, are being snapped up by employers who value them for these qualities rather than for their specific technical training", the IDS says.

Relatively high median salaries for university professors and lecturers ( $£ 21,000$ for chemists) "merely reflect the fact that the age distribution is so different from that in other occupations, with the university employees concentrated in the older age groups," the report says.

Simon Hadlington

'IDS study 408, Engineers' and Scientists' Pay (193 St John Street, London EC1V 4LS)

\section{Euroregulations proposed for modified organisms}

\section{London}

No release of a genetically modified organism will be allowed within any country of the European Communities (EC) without the other members having a chance to object, if new proposals by the Commission of the EC are adopted. The Commission itself will be the final court of authority should any country object on grounds of safety to the sale on its territory of an organism that has received national approval elsewhere

The Commission's proposals are an attempt to 'harmonize' regulations within Europe. They deal not only with the release of genetically modified organisms but also with their use in contained conditions, ranging from academic laboratories to production plants.

Each use of genetically modified organisms will have to be notified to a relevant national authority, except in the case of the contained use in non-industrial laboratories or microorganisms classified as 'minimal hazard'. For some uses, notification will be largely a matter of routine, but as the potential risk attached to the experiment or process increases so will the degree of endorsement necessary.

The Commissions's proposals will now be subject to scrutiny by the Council of Ministers and the European Parliament, and will be scrutinized by environmental and industrial groups. In view of the widely divergent current position of EC countries on regulations, ranging from the highly permissive (such as Italy) to the highly restrictive (such as may be adopted in West Germany - see Nature 332, 672; 1988 ), it is unlikely that the proposals will be converted into a binding directive in the immediate future. Peter Newmark 